\title{
Spatial Interaction Between Regions: Study of the East Kalimantan Province, Indonesia
}

\author{
Adi Wijaya ${ }^{1}$, Surya Darma ${ }^{2 *}$, Dio Caisar Darma ${ }^{3}$ \\ ${ }^{1}$ Department of Economics, Faculty of Economics and Business, Mulawarman University, Samarinda 75117, Indonesia \\ ${ }^{2}$ Department of Agrotechnology, Faculty of Agriculture, Mulawarman University, Samarinda 75119, Indonesia \\ ${ }^{3}$ Department of Management, Sekolah Tinggi Ilmu Ekonomi, Samarinda 75242, Indonesia
}

Corresponding Author Email: uyadarma60@gmail.com

https://doi.org/10.18280/ijsdp.150618

Received: 21 June 2020

Accepted: 16 August 2020

\section{Keywords:}

quadrant regions, center for growth, spatial interaction, hinterland, attractiveness, potency, hierarchy

\begin{abstract}
City morphology can be formed due to interaction either spatially or the socio-economic community in it. This study aims to determine the classification of fast-growing and growing quadrant areas in East Kalimantan Province, the central growth region and the highest relationship between spatial interactions between the growth centers and the hinterland region. The type of this research is quantitative descriptive research because this research is presented with numbers during 2014-2018. Data used is based on secondary data obtained from the site of the Central Statistics Agency and other related agencies. The analytical tool used is the Klassen Typology and Gravity Index, then processed using Microsoft Excel. The results of the empirical study show that there is one area in East Kalimantan Province that is classified as Quadrant I (Fast Forward and Growing Area), namely East Kutai Regency, and there are dominant seven regions classified in Quadrant III (Rapid Developing Areas), and none occupy Quadrant I (Disadvantaged Region). The area is the center of growth in East Kalimantan Province, namely Berau Regency. Meanwhile, Samarinda City with the highest spatial interaction (attractiveness and potential) with a growth center in Kutai Kartanegara Regency (hierarchy I).
\end{abstract}

\section{INTRODUCTION}

Theoretically, spatial interactions require a deepening of regional hierarchies. The relationship between groups of tributaries and hinterlands, making it a system in a hierarchical network. Several previous studies have discussed spatial interactions and their relevance to local interior boundaries. The focus of the driving forces and determinants of urban growth through physical, socio-economic, and environmental factors, makes remote areas such as support areas (such as villages), also able to develop. Because, basically the regional economy is closely related to space, distance, travel time, and transportation costs $[1,2]$.

The city is a residential area in which there are various social and economic activities, where there are supporting facilities to support community activities in the area. Cities can be seen from population density, legal status, administrative boundaries, and interests. The development of cities in Indonesia is developing cities that are influenced by economic factors and the mobility of the people who are active in a city area.

The theory of regional interaction forces was introduced by Reilly [3] who adopted Isaac Newton's theory of gravity. In the theory of regional interaction strength, the strength of regional interaction is measured by focusing on the comparison of the number of inhabitants with the distance between regions. The theory of the strength of regional interaction can apply if it meets the same topographic (homogeneous) regional conditions, the socio-economic conditions of the same community and the conditions of the same transport infrastructure and facilities [4, 5].

The growth center can be interpreted in two ways namely functionally and geographically. Functionally, the center of growth is a location of the concentration of business groups which, due to the nature of the relationship, have dynamic elements to stimulate economic life, both inside and outside. When viewed geographically the center of growth is a location that has many facilities and facilities so that it becomes a center of attraction that causes various businesses to be interested to be located there and the community likes to come to take advantage of existing facilities. To determine the Regency / City in East Kalimantan Province which is the center of growth in this study uses a scalogram analysis, a centrality index with an ordinal scale $[6,7]$.

The establishment of a National Strategic Area (KSN) oriented towards economic activities causes the need for regional integration and interaction to support mutual economic activity. The position that is close together will cause a great strength of interaction and integration [8-10].

This is due to the high differences in needs between regions [11-14]. The limited resources of each region will reflect the need for interaction within the region [15-18].

Samarinda as the center of the capital always attracts people from outside the region (inside and outside Kalimantan) to migrate to improve the economy, social status, and so on, so that it has a population compared to other regions. For 5 years, big cities such as Balikpapan contributed the second largest population level, and Bontang City with the third-largest population for East Kalimantan Province. On the other hand, there is 1 region with the least population, namely the District 
of Mahakam Ulu. This new division area after 2013 from West Kutai Regency, has 5 subdistricts and is still sparsely populated from outside the area to dominate in Mahakam Ulu, due to constrained access to adequate infrastructure facilities and infrastructure, as well as other factors. North Penajam Paser is a region resulting from the division of Paser Regency which has a population that is still categorized as the bottom three based on the data in the lower table compared to Berau, even though this region can be said to have a short distance from the main research city, namely Balikpapan, which has an economical economy. both with proximity to developed cities usually, will affect other regions to develop and are identical with high population density, but most likely still have a small population affected by employment opportunities or the lack of availability of existing service facilities [19].

Newton's laws of motion provide an analogical basis for modeling spatial interactions in geographical systems. After classical physics was founded at the end of the $17^{\text {th }}$ century, scientists and philosophers argued that the forces that occur in the social world can be modeled in the same way as in the physical world. Initial attempts for such generalizations were made, but the most explicit application was made by Ravenstain in 1888. During the first half of the 20th century, the gravity hypothesis for various problems of movement and interaction in the human system became popular. Most important among these is the adaptation of Reilly's [20] gravity model to allow interior boundaries to be drawn between different shopping centers based on points where shopping flows to competing centers are alike. The gravity model adapted by Reilly is the model that will be used in this study. This model is used to measure the strength of regional interaction in East Kalimantan Province.

Referring to some phenomena that have been described before, researchers are interested in discussing the classification of quadrant regions in the fast-growing and growing East Kalimantan Province, the growth center region and the highest spatial interaction relationship between the growth center region and the hinterland region.

\section{LITERATURE REVIEW}

\subsection{Spatial interaction}

The region is a continuous area that lies between the local and national level. It was also stated that defining the region itself depends on the objectives of the analysis of the objectives of the formulation of regional development policies to be prepared [21, 22].

In Indonesia, the notion of territory has been defined in the Law of the Republic of Indonesia No. 26 of 2007 concerning Spatial Planning, namely a region is a space which is a geographical unit and all related elements whose boundaries and systems are determined based on administrative or functional aspects.

The classification of the area above is not much different from the classification proposed by Tarigan [7]. The region is defined as a geographical unit that has a certain place without paying too much attention to the boundaries and conditions. Regions according to their types can be divided into 3 types: (1) Homogeneous regions, namely regions which have uniform characteristics. The uniformity of these characteristics can be seen according to economic factors, geographical, socio-cultural and other aspects;
Heterogeneous regions, namely regions that are functionally interconnected due to heterogeneity (inequality). These regions are complementary but with different functions, generally taking place between the central area (core) and periphery (hinterland); and (3) Planning areas, namely administrative areas which are in a united policy or administration. Examples are regions classified as Provinces, Cities, Regencies, Districts, and Villages.

Relationships that occur between these areas cause the activities of an area cannot be separated from the surrounding area, or commonly referred to as a reciprocal relationship. Interactions that often occur between regions and have a reciprocal relationship usually occur between urban and rural areas. The interaction of villages and cities can be seen from the shifting of the livelihoods of rural communities from agrarian to nonograms, the emergence of commuters because they are supported by adequate transportation facilities, trade in agricultural and industrial products, and advances in education. The interaction of cities and villages largely determines the distribution patterns of rural and urban communities, explained as follows: (1) Quadrant I: shows the flow of goods and services produced by economic sectors to be used in the production process. Transactions that occur in quadrant I are better known as transactions between; (2) Quadrant II: shows the final demand for imports and overall describes the supply of goods and services. Final demand consists of household consumption, government consumption, investment, and exports; (3) Quadrant III: shows the primary inputs of economic sectors and is not an output of production activity. Coverage of primary inputs includes remuneration for factors of production in the form of salary wages, business surpluses, depreciation and net indirect taxes; and (4) Quadrant IV shows primary inputs that are directly distributed to the final demand sectors. This information is used in the Social Economic Balance System (SNSE).

SI models consider flows between origins (i) and destinations (j). Typically, the goal is to understand the flows or trips $\left(T_{i j}\right)$ between $i$ and $j$, and possibly to predict them in a future scenario. In a generic sense, the flows are a function of the spatial separation between $\mathrm{i}$ and $\mathrm{j}$, as well as the characteristics of origins and destinations [23]. Most SI models start with spatial interaction flows and treat them as dependent variables; these are modeled with independent effects including: (1) A push factor representing the propulsiveness of each origin (e.g., the number of households in an origin zone); (2) A pull factor representing the attractiveness of each destination (e.g., size of a shopping center); and (3) A measurement of the spatial separation between origins and destinations (e.g., time, cost, or distance to overcome).

\subsection{Linkages between regions}

Intra-sectoral and inter-sectoral linkages of economic linkages describe the relationship between the economy of a region and its surroundings and agglomeration externalities are seen as important determinants in the geographical concentration of economic activity in urban areas. Intersectoral linkages (inter-company links in the same sector) and inter-sectoral links are a way to see agglomeration externalities, whether triggered by inputs or suppliers and outputs or customers [17].

Douglas [24] describes the relationship between cities and villages in the form of interdependence, rather than a one-way 
city-to-village or village-to-city relationship. Urban-village linkages can be seen as mutually reinforcing. This is consistent with what Kasikoen [22] states that urban-rural linkages can be in the form of complementary or exploitative links.

\subsection{Mobility}

Mobility can be interpreted as the level of fluency and can be measured by the number of trips (movement) from one location to another as a result of the high level of access between these locations. That means, between accessibility and mobility there is a direct relationship, i.e. the higher the access, the higher the level of mobility of people, vehicles or goods moving from one location to another [25].

In order to encourage the smooth mobility of people and goods policies that are commonly carried out by most developing countries is to increase and accelerate the development of inter-regional transportation networks. The transportation network includes highways to encourage land transportation activities. The better a transportation network, the better the accessibility, so that economic activity is also growing [26].

Various kinds of contributions in the economy that discuss the nature, motives, and implications of the location of production can be found, depending on the mobility of the population [27].

\subsection{Growth of pole theory}

The center of growth (growth of pole) can be interpreted in two ways, namely functionally and geographically. Functionally, the center of growth is a location of concentration of business groups or branches of industry which, due to the nature of the relationship, has dynamic elements so as to be able to stimulate economic life both inside and outside (behind it). Geographically, a growth center is a location that has many facilities and facilities so that it becomes a center of attraction, which causes various kinds of businesses interested to be located there and the community likes to come to use the facilities in the city, although there is probably no interaction between businesses. the business. Not all generative cities can be categorized as centers of growth $[7$, 28].

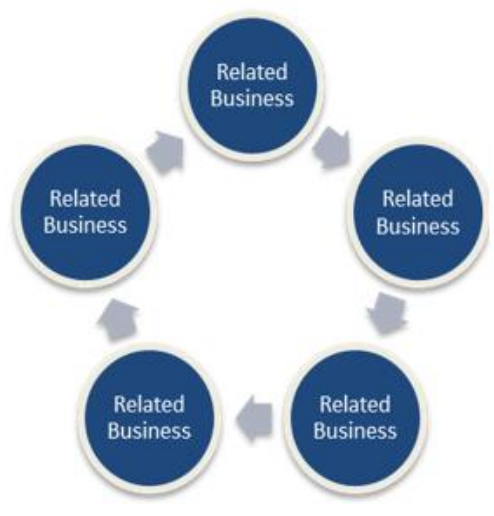

Figure 1. Economic structure of growth centers Source: Sjafrizal (2008)

The growth center must have the following characteristics: (1) There is an internal relationship between various activities that have economic value; (1) The multiplier effect; (3) There is geographical concentration; and (4) Are encouraging the growth of the area behind it. In general, the economic structure of the growth center can be described in Figure 1.

Another opinion put forward by Adisasmita [29] which states that economic growth at the center of growth will affect the area behind it through the effect of polarization and trickling down effects. The polarization of these effects is strengthened by the concentration of investment in the center of growth, while the trickling down effect can grow by increasing the attractiveness of the surrounding area.

\subsection{Economic growth}

Theoretical models of the new growth theory suggest that economic growth results from increasing returns are associated with innovation and the diffusion of new knowledge $[30,31]$. In these models, it is argued that different types of geographical space matter in the innovation process since important parts of new knowledge have some degree of tacitness. Tacit knowledge is embedded in the routines of individuals and organizations, and, thus, difficult to transfer across space.

In economic development, the evaluation of regional economic theory is needed with consideration of conceptualization that presents the nature and trajectory of the globalization process. This certainly creates a contrast, because the theoretical insights and empirical evidence produced by various developed and developing countries in the economic field require an institutional role and revolution. So far, in the era of globalization, acceleration is needed to improve regional processes and local roles, thus shaping the development trajectory. This process seeks to systematize scientific knowledge about clusters, characteristics, stages, and peculiarities of territorial distribution for long-term prospects for regional development [32-35].

In other words, that economic growth refers more to changes in a quantitative nature (quantitative change) and is usually measured using data on Gross Domestic Product (GDP) or income or market final value of final goods and services produced from an economy during a certain period (usually one year)

Economic growth is strongly influenced by the ability of the economic sector (business sector) to produce goods and services. The economic sector is currently grouped into 17 sectors, namely: (1) Agriculture, forestry and excavation; (2) Mining and quarrying; (3) processing industry; (4) Procurement of electricity, gas; (5) water supply, waste management, waste, and recycling; (6) Construction; (7) Wholesale and retail trade, car and motorcycle repair; (8) Transportation and warehousing; (9) Provision of accommodation and food and drink; (10) Information and communication; (11) Financial and insurance services; (12) Real estate; (13) Company services; (14) Government administration, defense, and mandatory social security; (15) Educational services; (16) Health services and social activities; and (17) Other services [36].

\subsection{Gross regional domestic product and per capita income}

One of the important indicators to determine the economic conditions in an area in a given period is the GRDP data, both at current prices and at constant prices. GRDP is the amount of added value generated by all business units in a given area or is the total value of final goods and services produced by all economic units [37]. 
Regional income is the level of community income in the analysis area. To measure the existence of development in an area is marked by an increase in community income. Regional development must be related to an increase in community income in the area, what is meant is the average income of the community [38]. The term used to describe regional income from this study is Gross Regional Domestic Product (GRDP) or per capita income.

Per capita GRDP is one indicator derived from the GRDP figure. This figure can be obtained by dividing the GRDP figure of a year with the mid-year population in that area. Per capita GRDP that shows PDRB value per head or population is not a tool to measure welfare because the value of the GRDP is not necessarily owned by residents of the region.

\subsection{Conceptual framework}

The inhomogeneity of a region in an area both in terms of population, climate, weather, and even social and economic facilities causes the nodal and spatial regions of the functional nodal region to have interdependence between the center and the regions behind it (hinterland). In the nodal region usually grows faster than the back region because in the nodal region has the advantage of economic agglomeration and a centralized distribution of a population [39].

However, not all of the nodal areas experience growth evenly, but often some points are driving the development of nodal activity activities called the growth centers. Therefore, to accelerate the increase in income there is a need to build one or more centers of economic power in a country or region. The role of the polar growth in regional development is as the main driving force or growth locomotive which then spreads the results of development and the impact of growth on the area of influence [29].

In this research, the area mapping will be done first by using the Klassen typology analysis tool. Klassen typology analysis is used to see the state or position of the economy in an area, which is divided into four quadrants. The first quadrant is a fast-developed and growing region, the second quadrant is a developed but depressed region and the third quadrant is a fastdeveloping region, while the fourth quadrant is a relatively left behind region. Then, the results of the Klassen's typology analysis will be explored empirically and more thoroughly about phenomena.

After the growth center region is found, then in this study, we will look for spatial interactions between the growth center region and the surrounding area using the gravity index. Gravity index is used to find out how much the value of interaction of growth centers with the surrounding area. The highest interaction value shows that between regions has a strong spatial interaction, the variable used in the analysis of the gravity index uses the variable number of residents with the distance between regions. The results of this gravity index will also be scaled to obtain a ranking (priority determination) of the strength of the interaction with the ordinal scale (see Figure 2).

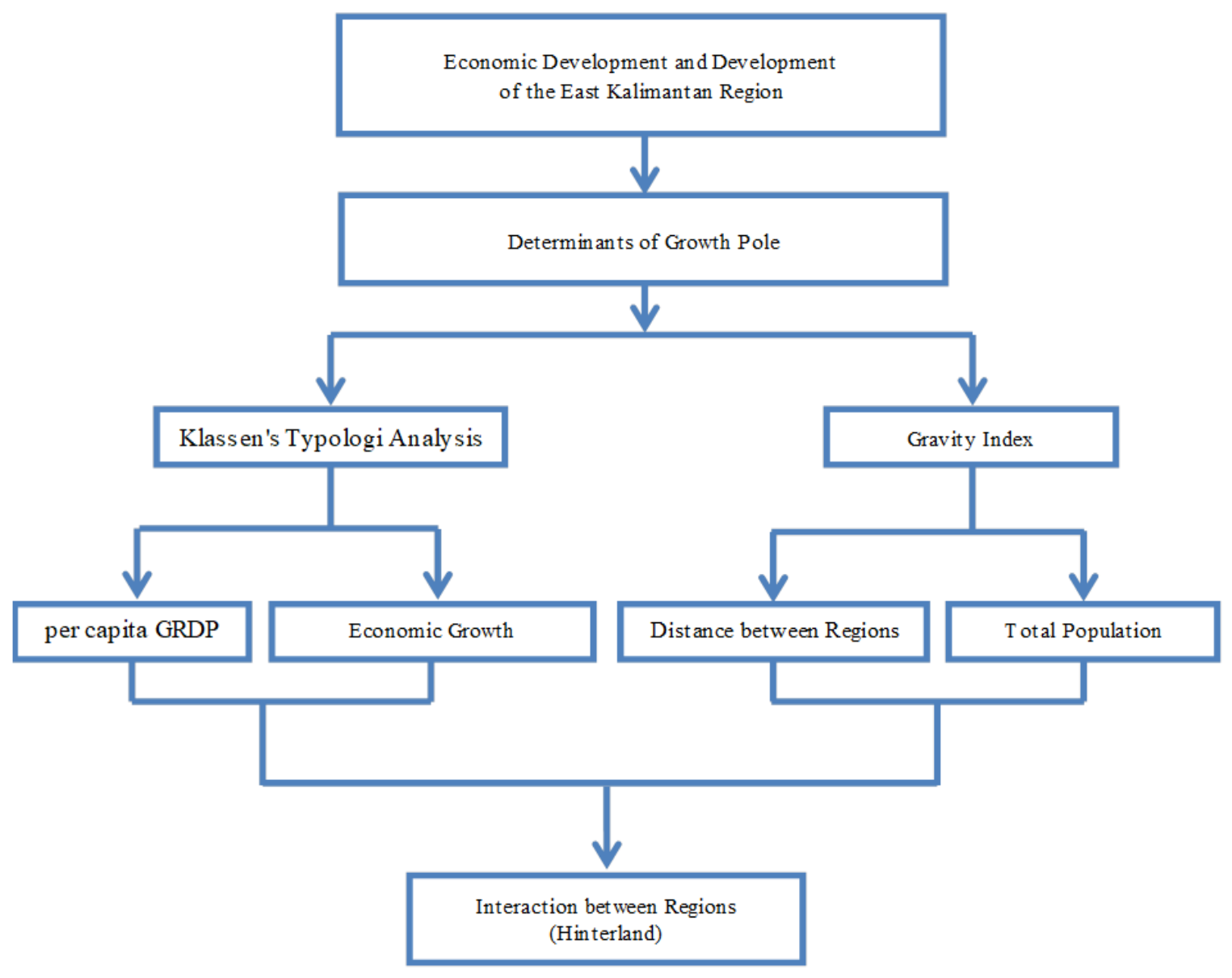

Figure 2. Economic structure of growth centers [12] 


\section{METHODS}

\subsection{Research design}

This type of research is quantitative descriptive research because this study is presented with numbers. This is in accordance with the opinion of Arikunto [40] who stated that quantitative research is a research approach that is demanded to use numbers, starting from data collection, interpretation of the data, and the appearance of the results. The type of data used in this study is secondary data. Secondary data is data that has been collected by data collection agencies and published to the data user community [41]. Secondary data used were obtained from economic statistics, such as BPS-Statistics, Planning and Development Agency of East Kalimantan Province, and related agencies.
The object of research is the regional unit in East Kalimantan Province, which consists of 10 regions (regencies/cities) during 2014-2018. Data analysis using Klassen Typology and Gravity and processed using Microsoft Excel 2010. The following is a summary of the types and sources of data used by researchers (Table 1).

Determining the growth poles is a serious concern and is needed to encourage the sustainability of economic growth between regions [42]. For this reason, there is a logical demonstration, and rationality of the analysis used (Klassen's Typology and Gravity Index) is needed to answer the study problem. The two analysis models cannot be combined, but rather aim to solve 2 different problems in this study. Both also have different measuring tools and indicators, so that only a comparison of the explanations that we have determined.

Table 1. Indicator variables, units, sources, and amount of data

\begin{tabular}{|c|c|c|c|}
\hline Indicator Variables & Units & Sources & Data \\
\hline $\begin{array}{l}\text { Gross Regional Domestic } \\
\text { Product (GRDP) per capita }\end{array}$ & Rp. Million & BPS-Statistics of East Kalimantan Province & 5 years \\
\hline Economic Growth & 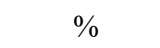 & $\mathrm{BP}$ & rs \\
\hline Tot & People & atistics of East Kalimantan Province & 5 years \\
\hline $\begin{array}{l}\text { Distance between Regions } \\
\text { (towards the Capital) }\end{array}$ & $\mathrm{Km}$ & $\begin{array}{c}\text { Planning and Development Agency of East } \\
\text { Kalimantan Province }\end{array}$ & 5 years \\
\hline
\end{tabular}

Source: Authors design

\subsection{Measurement}

Measurement of a variable is a resolution given to a variable or construct by means of giving meaning, or specifying an activity or providing an operation needed to measure the construct or variable [43].

The operational definitions and measurement variables in this study is average per capita Gross Regional Domestic Product (GRDP) of each Regency / City in East Kalimantan Province in 2014-2018. Data on average per capita GRDP is obtained from the calculation of GRDP based on constant 2010 prices divided by the number of residents each year, after that it is added up and divided by the number of years. GRDP at constant prices shows the added value of goods and services calculated using prices that apply to a certain year as the base year. The GRDP data can be used to show the overall economic growth rate or each sector from year to year. In this study, the per capita GRDP is stated in the size of Rp. Million.

Second, average economic growth in each Regency / City in East Kalimantan Province in 2014-2018. The rate of economic growth is data that shows the aggregate development of income from a certain time to the previous time, obtained by reducing the value of GRDP (at constant 2010 prices) in the n-year (base year) to the value in an $n-1$ year (a year before) divided by the GRDP value of the $n-1$ year, multiplied by $100 \%$. By adding up the calculation results each year and for the number of years the average value is obtained. In this study, the rate of economic growth is expressed as a percentage $(\%)$.

Third, the total population of each Regency / City in 20142018 The population is individuals or household members who reside in each region excluding foreign tourists, domestic who live for less than 6 months, crew or aircraft who are visiting, foreign and domestic entrepreneurs who have lived for less than 6 months, members of the Diplomat and Consulate, and seasonal workers. In this study, population numbers are expressed in terms of soul size (people).
Fourth, distance is a variable that is often used to determine the attraction or strength of interaction that is owned between one region to another. The distance between regions is a measure of the distance between the two regions taking into account the main routes of the shortest highway. Distance is a variable that can be expressed in terms of physical size, time, price and others between Regencies / Cities in East Kalimantan Province during 2014-2018. In this study, distance is expressed in physical size $(\mathrm{Km})$.

There are 10 areas in Kalimantan Province that need to be improved and identified to determine which ones are most appropriate to be developed as new growth poles through the Klassen Typology model. Meanwhile, the hope for the creation of new growth poles, the development of economic performance, and its infrastructure will extend outward to the interior and eventually create equally developed regions which are analyzed through the analysis of the Gravity Index.

\subsection{Analysis model}

\subsubsection{Klassen's typological analysis}

Klassen typology analysis is used to find a picture of the conditions and structure of economic growth in an area associated with the above economy [44]. In the East Kalimantan Province and is divided into four quadrants from the first quadrant is a region that is fast progressing and fastgrowing, that is, an area that has a per capita GRDP and growth rate that is superior to the reference region.

The second quadrant is a developed but depressed region, that is, a region that has a higher GDP per capita level compared to the reference region, but the rate of economic growth is smaller than the reference region.

The third quadrant is a fast-developing region, this region has a smaller GDP per capita level compared to the reference area, but the rate of economic growth is greater than the reference region.

The fourth quadrant is a relatively underdeveloped region that is a region that has a per capita GRDP level and a rate of 
economic growth that is smaller than the reference area.

Klassen Typology Analysis, which is used to find out about the patterns and structures of economic growth in each region $[45,46]$. The Klassen approach was adopted and made operational, which consists of two main indicators namely the rate of economic growth (based on the constant price of 2010) and the level of per capita GRDP in 10 regencies/cities of East Kalimantan Province which are formulated as follows (Table 2):

\begin{tabular}{c|c}
$\begin{array}{c}\text { QUADRANT I } \\
\text { (Fast Progressing } \\
\text { and Fast-Growing) }\end{array}$ & $\begin{array}{c}\text { QUADRANT III } \\
\text { (Fast-Developing Region) }\end{array}$ \\
\hline $\begin{array}{c}\text { QUADRANT II } \\
\text { (Developed but }\end{array}$ & QUADRANT IV \\
Depressed Region) & (Relatively \\
Underdeveloped Region)
\end{tabular}

Figure 3. Klassen typology quadrant

Table 2. Regional typology analysis formulas

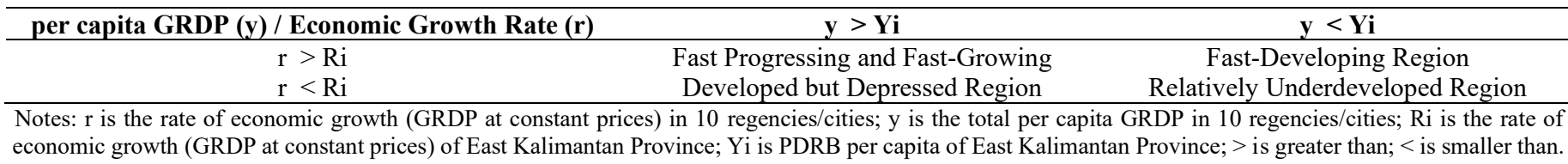

\subsubsection{Gravity index analysis}

The basic concept of this analysis tool is to discuss the size and distance between two places, namely the center of growth with the surrounding area, to how far an area that is a center of growth affects and interacts with the surrounding area [47].

From some of the measurement tools that are often used are the population, this is because the population data is easy to get, in addition to that the population is very directly related to various other measurements that are announced above. The second factor that influences the interaction is the distance between cities A and B. Distance affects the desire of people to travel because it takes time, energy, and money to travel. The longer the distance separating the two locations, the lower the desire for people to travel [38]. The general gravity formula is as follows:

$$
I_{i j}=k \frac{p_{i} p_{j}}{d_{i j}{ }^{b}}
$$

Furthermore, the use of the gravity formula can be simplified into [44]:

$$
I=\frac{p_{1} p_{2}}{d^{2}}
$$

where, $I$ is the amount of interaction between cities/regions A and $\mathrm{B} ; p_{1}$ is the population of the city/region $i$ (thousands of inhabitants); $p_{2}$ is the number of inhabitants of the city/region $\mathrm{j}$ (thousands of inhabitants); $d_{i j}{ }^{b}$ is the distance between city $i$ and city $j(\mathrm{~km}) ; \mathrm{k}$ is a constant based on experience; $b$ is the rank of $d_{i j}$ that is often used $b=2$.

If an area or region has the highest $T_{i j}$ value compared to other regions, then that region is the main central area or growth point that will be owned by that region. The greater the number of interactions obtained by a region, the closer the region's relations with other regions. In this case, it means that the region has more potential to develop due to the close interrelationship between economic activities.

The basic concept of the gravity analysis tool in this study is to discuss the size of the distance between the growth center and the surrounding area, to how far an area that is the center of growth affects and interacts with the surrounding area. The greater the value of the interaction shows the closer interaction between the growth center and the surrounding area (hinterland). The interaction is in the form of economic relations between regions (regencies/cities in East Kalimantan Province) and the social community. To facilitate the determination of priority areas that have strong spatial interactions between the growth center and the surrounding area, the results of gravity calculations will be ranked using the ordinal scale.

\section{RESULTS}

\subsection{Determination of quadrant area}

Klassen's typology is one of the regional economic analysis tools that can be used to determine the classification of regional economic sectors in 10 regencies/cities. Klassen's Typology analysis model is used with the aim of identifying the position (mapping) of the quadrant area in the Regency / City by taking into account 2 indicators namely the rate of economic growth and per capita GRDP at the level of the Province of East Kalimantan as a reference area.

The Klassen Tipology method is used to find out the grouping of economic sectors between regencies/cities in East Kalimantan Province according to their growth structure. By using the Klassen Matrix, four sector groupings can be made by utilizing the rate of economic growth and the value of contributions (per capita GRDP), which compares a regency/city with the provincial level.

During 2014-2018 the results of the approach with the Klassen Typology analysis in 10 regencies/cities in East Kalimantan Province that only three classifications of quadrant regions were filled. In Quadrant I (Advanced and Fast-Growing Regions) it is evident that East Kutai Regency is able to fill that position. Quadrant II (Advanced but Distressed Region) is filled by two regions namely Kutai Kartanegara Regency and Bontang City. Then, Quadrant III (Fast Developing Regions) is dominated by seven regions namely Paser, West Kutai, Berau, North Penajam Paser, Mahakam Ulu, Balikpapan City, and Samarinda. Meanwhile, none of the regions inhabited in Quadrant IV (Relatively Disadvantaged Regions) 
Table 3. Average regency / city position in East Kalimantan Province according to the klassen typology criteria

\begin{tabular}{ccc}
\hline per capita GRDP (y) Economic Growth Rate (Yi) & $\mathbf{y ~}>$ Yi & y $<\mathbf{~}$ \\
\hline $\mathrm{r}>\mathrm{Ri}$ & East Kutai (Quadrant I) & $\begin{array}{c}\text { Paser, West Kutai, Berau, North } \\
\text { Penajam Paser, Mahakam Ulu, } \\
\end{array}$ \\
& & Balikpapan, Samarinda (Quadrant III) \\
\hline $\mathrm{r}<\mathrm{Ri}$ & Kutai Kartanegara, Bontang (Quadrant II) & (Quadrant IV) \\
\hline
\end{tabular}

Source: Authors calculation

Table 4. Results of gravity analysis of samarinda city and surrounding areas in East Kalimantan Province

\begin{tabular}{ccc}
\hline Gravity Interaction & D $_{\text {ij }}$ (Interaction Value between Regions) & Hierarchy \\
\hline Samarinda - Paser & 3.15 & VI \\
Samarinda - West Kutai & 1.06 & VII \\
Samarinda - Kutai Kartanegara & 606.77 & I \\
Samarinda - East Kutai & 8.41 & IV \\
Samarinda - Berau & 0.57 & VIII \\
Samarinda - North Penajam Paser & 7.41 & V \\
Samarinda - Mahakam Ulu & 0.06 & IX \\
Samarinda - Balikpapan & 39.86 & II \\
Samarinda - Bontang & 11.37 & III \\
\hline
\end{tabular}

Source: Authors calculation

This is similar to what happened with typology in 2014. The comparison of the rate of economic growth (GRDP at constant prices) and the amount of GDP per capita in 10 districts/cities to the rate of economic growth and the magnitude of per capita GRDP in East Kalimantan Province can be explained by quadrant analysis. When examined through the results of the analysis in the past 5 years, the East Kutai regency was recorded as inhabiting Quadrant I, which means that when viewed from both sides, namely the ratio of economic growth (GRDP) and magnitude of per capita GRDP because there is a higher area than the Kalimantan Province figures East (see Table 3).

In the other component, Quadrant II has been occupied by two regions namely Kutai Kartanegara and Bontang Regencies, where the growth rate under the Province is still per capita GRDP above the Provincial figures. Meanwhile, when reviewed in Quadrant III, it is also noted that some Regencies / Cities group and dominate, namely: Paser, West Kutai, Berau, North Penajam Paser, Mahakam Ulu, Balikpapan City, and Samarinda. This condition shows that the position of the GRDP growth rate of each regency/city is higher than the GRDP growth rate of East Kalimantan Province. On one hand, there are no regions that occupy Quadrant IV or show districts/cities that both the economic growth rate (GRDP) and per capita GRDP are lower than in East Kalimantan Province.

\subsection{Spatial interaction patterns}

Gravity analysis is used to determine the strength of regional interaction between Regencies and Cities in East Kalimantan Province. Gravity analysis in this study makes Samarinda City as a destination because, in the Klassen Typology analysis process, Samarinda City is an area that serves as a regional service center (Provincial Capital) of East Kalimantan so that this area has a strong appeal to attract Regency / Other cities in East Kalimantan Province.

Based on the results of gravity analysis, the strength of the spatial interaction between Samarinda City and other regions in East Kalimantan Province was obtained from 2014-2018. The strength values are presented in Table 4.

It can be seen that strong regional interactions occur between Samarinda City and Kutai Kartanegara District (rank I), Bontang City (rank III), and Balikpapan City (rank II) with gravity values ranging from 2 - 650. The strength of regional interactions is occurring between- Samarinda City region to Paser Regency (rank VI), East Kutai Regency (rank IV), North Penajam Paser Regency (rank V) which have a gravity value ranging from 1-10. Meanwhile, the strength of regional interaction which is classified as weak is the regional interaction between the City Samarinda with West Kutai District (rank VII), Berau District (rank VIII) and Mahakam Ulu Regency (rank IX) at gravity intervals 0 to 1 . To see graphs of gravity strength between Samarinda City and surrounding areas can be seen in Figure 4.

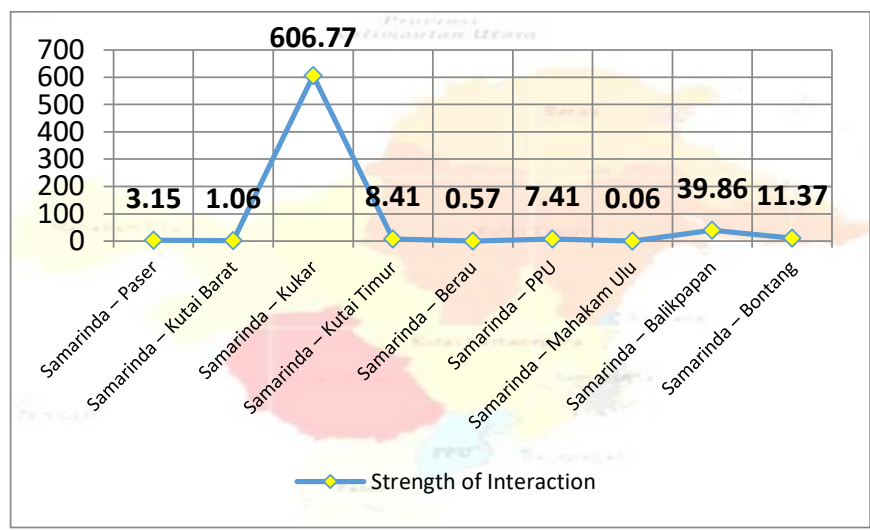

Figure 4. Linear strength of Samarinda's spatial interaction against other Regions in East Kalimantan Province Source: Authors calculation

It appears that the linear line has a positive curve and rises significantly in the interaction section between Samarinda City and Kutai Kartanegara Regency and the linear line curve moves downward when it passes through the interaction section between Samarinda City and West Kutai Regency, Berau Regency, Mahakam Ulu Regency, and Bontang City.

Several factors (reasons) the researcher did not specify the spatial in the structure of Gravity Analysis per year as in the previous analysis study (Klassen Tiplogi), because there are the same ranks or hierarchies for 5 periods (2014-2018), the number of population between districts / cities in The province of East Kalimantan continues to move in a positive direction with a presentation of an increase of $10-20 \%$, and the distance 
of the location that connects the capital center of East Kalimantan (Samarinda) to other regions in 2014-2018 has not changed. The results of the spacial interaction ranking calculation also did not experience significant changes or were relatively constant, so it was enough to take the average strength (median) value of gravity.

\section{DISCUSSIONS}

\subsection{Classification interaction between quadrant regions}

The three aspects of planning that have always been applied as a reference in development (macro planning, sectoral planning, and regional planning), all three of which are arranged in one unit. This publication is intended specifically to support regional planning, especially to see the achievement of the GRDP figure which is the total added value created as a result of sectoral activities in processing goods and services from Regencies / Cities in East Kalimantan Province during the 5 periods, namely 2014-2018.

Regencies / Cities in East Kalimantan Province, each of which has different characteristics from one another. This difference can cover the area, population, natural resources owned, facilities and pre-transportation facilities as well as other things, which will then influence the development of each region. Therefore, by using the Klassen Typology approach a mapping of the conditions of the entire Regency / City can be carried out, so that the characteristics of each region can be known.

Serial presentation aims to see the level of change to see the level of change or the development of the rate of economic growth, the number of GRDP and Per capita GRDP based on constant prices in each of 10 regencies / cities in 5 years. The development of these values illustrates changes in the level of population prosperity that occurred during the study period. In general, for analysis, in the measurement of the level of prosperity in real terms, a constant price calculation is used. But to see the total effect (a combination of quantum and price) that occurs, the measurement through Per capita GRDP (based on constant prices) becomes a benchmark in this study.

In the previous data display, it also shows that it turns out that a high GRDP does not all have an impact on the rate of economic growth evenly in several regions. Another factor that can influence the magnitude and growth of per capita GRDP is very high in 2018, compared to 2014 is the depreciation factor of foreign currencies, because the largest composition in the formation of regency / city GRDP in East Kalimantan comes from commodities traded for export so in the cycle of foreign trade these commodities are strongly influenced by factors of the exchange rate of the Dollars (USD) against the Rupiahs (IDR).

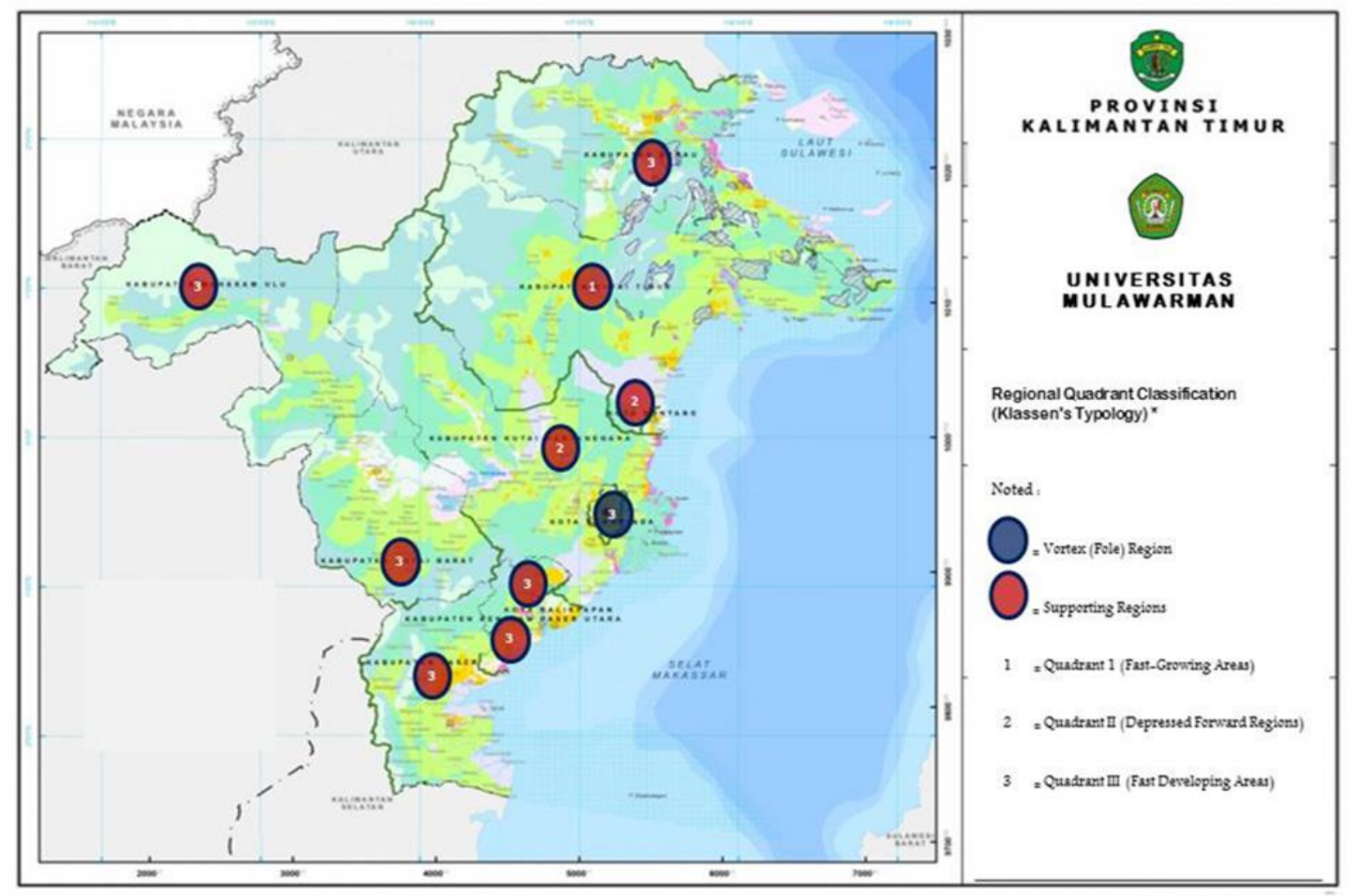

Figure 5. Regional quadrant cluster in East Kalimantan Province based on Klassen's Typology Source: Authors calculation

Through the Klassen Typology approach by using a basis on several variables, namely: the rate of economic growth and per capita GRDP based on 2010 constant prices and from the total (total) originating from each city / regency and average in East Kalimantan Province. From 10 regencies / cities in East Kalimantan Province. Later, it will be seen among the regions that are classified in Quadrants I to IV (lagging areas until developed and fast growing. Although in the perspective of 
natural and economic resources in East Kalimantan Province is very abundant, so the need for the role of the Government in making policies in its management With quadrant area, later the regions of fast-moving regions will be classified and grow until the regions are relatively left behind (see Figure 5).

In line with the previous empirical results, for 5 periods there was not a single region that occupied the Quadrant IV (Relatively Disadvantaged Region), while the dominant was in position III (Fast Developing Region), and the rest was in the Forward but Depressed Region (Quadrant II) and the Region Fast Forward and Grow (Quadrant I).

Some reasons make the region dominant, precisely 7 regions (Paser Regency, West Kutai, Berau, North Penajam Paser, Mahakam Ulu, City of Balikpapan, and Samarinda) are in position 3, among others: (1) GRDP value based on constant 2010 regional prices This is not so big when compared to some regions in Quadrant I or II, but it has a large enough population, resulting in lower community income (per capita GRDP) than the comparison region, namely East Kalimantan; (2) The accumulation of the GRDP illustrated from the economic growth rates of these 7 regions does indeed appear above the average reference region, therefore the role of 17 sectors therein has a significant impact in contributing to the accumulation of economic growth in the province of East Kalimantan; and (3) Population in East Kalimantan Province still relies on primary-based economic structures, such as: Agriculture, Forestry, Fisheries, and Plantation, and Mining and Quarrying Sector, so in terms of employment and migration or population movement has not resulted in integration for the productivity of the community itself and other sectors or sub-sectors.

Meanwhile, from Quadrant II (Bontang City and Kutai Kartanegara Regency) it means Regional Advanced, but Depressed is suspected by contributions through the achievement of relatively high GRDP with a low population, resulting in a large per capita GRDP. When viewed from the contribution of regional GRDP to provincial coverage GRDP, Bontang City plays a role of around $10-11 \%$, on the other hand Kutai Kartanegara Regency is $25-30 \%$. From the scope of the level of economic growth, these two regions are still below the average economic growth at the level of East Kalimantan Province. It said "depressed", because for Kutai Kartanegara District the average growth in 5 years to the lowest point $-1.76 \%$, and at the same time for the City of Bontang was $-1.06 \%$. This is inversely proportional to the average economic growth in East Kalimantan Province, which is positive or at $1.11 \%$.

The Fast-forward and Fast-Growing Region (Quadrant I) is pinned to the East District region which has a better per capita GRDP performance and economic growth rate than the reference area, in this case the East Kalimantan Province. Both of these indicators, apparently reflected from the nominal PDRB Perapita of East Kutai Regency, on average during 2014-2018 reached IDR 201.75 Million compared to the level of the Province of East Kalimantan, which was IDR 154.88 Million. In line with empirical data also, that the economic growth rate of this region reached $2.22 \%$ (positive) and in the Province of East Kalimantan is only $1.11 \%$ with the same period. Besides, benchmarks on the size of the economy of the East Kutai Regency in the per capita GRDP and the rate of economic growth can also be felt for the welfare of its inhabitants, because almost all of the base sector lines have implications for other sectors and sub-sectors, so this region is considered appropriate as a center growth for the Province of East Kalimantan, both in the present, medium, and long term.

This was very much in keeping with traditional regional policy, and raised such questions as the selection of industries to be promoted in problem regions, the locational requirements of these industries, the types of investment necessary for such requirements to be satisfied, and the form and extent of financial assistance required to enable the industries to operate profitably $[45,48,49]$.

\subsection{Potential attraction interactions between regions}

Spatial interaction or spatial is a mutual relationship that influences each other between two or more regions which can cause new symptoms, appearances, or problems, because location or region is something that is taken into account in regional economic studies and the interactions that occur between them affect the speed development of the area concerned [50]. To find the strength of the spatial interaction between the growth center region and the hinterland region in this study using the gravity index.

The gravity index is used to find out how much the growth center interacts with its supporting region. The gravity index is based on a theory of the strength of regional interactions introduced by Reilly who adopted the theory of gravity of Isaac Newton [44]. In this theory, the strength of regional interaction is measured by focusing on the ratio of population to distance between regions. So, to find the gravity index in this study using the variable population with the distance between regions. Furthermore, the results of the gravity index will be scored with an ordinal scale, to facilitate the determination of the priority strength of interactions between regions.

Linkages are forms of the process of interaction between regions or regions resulting in a supply-demand relationship, which is supported by ease of relations and which can be beneficial (or detrimental) to the two regions / regions that interact. To find out the spatial strength of the regional interaction between Samarinda City and the surrounding area can be seen in Figure 6.

Based on the map it can be interpreted that, the direction of the flow of other regions (Regencies / Cities) flows towards the center of the Capital City of East Kalimantan Province. The direction of this flow of interaction means that, Samarinda City is the only regional service center in East Kalimantan that functions as a servant and supporter of other regions. The results of gravity analysis show that the strength of regional interactions that occur in East Kalimantan Province is directly proportional to distance. Weak strength of interaction between Samarinda City area which functions as a regional service center for West Kutai, Mahakam Ulu, and Berau Regencies is influenced by distance factors. The weak interaction indicates the inaccessibility of the three regions to the regional service center located in Samarinda City. Early anticipation that must be done to overcome this problem is to develop new service centers in the Sub-district areas where the interaction value is low or weak to core areas or regional service centers located in Samarinda City. Berau, West Kutai, and Mahakam Ulu are the three Regencies whose regional interaction value is weak, so that the region is the right region to develop new regional service centers. 


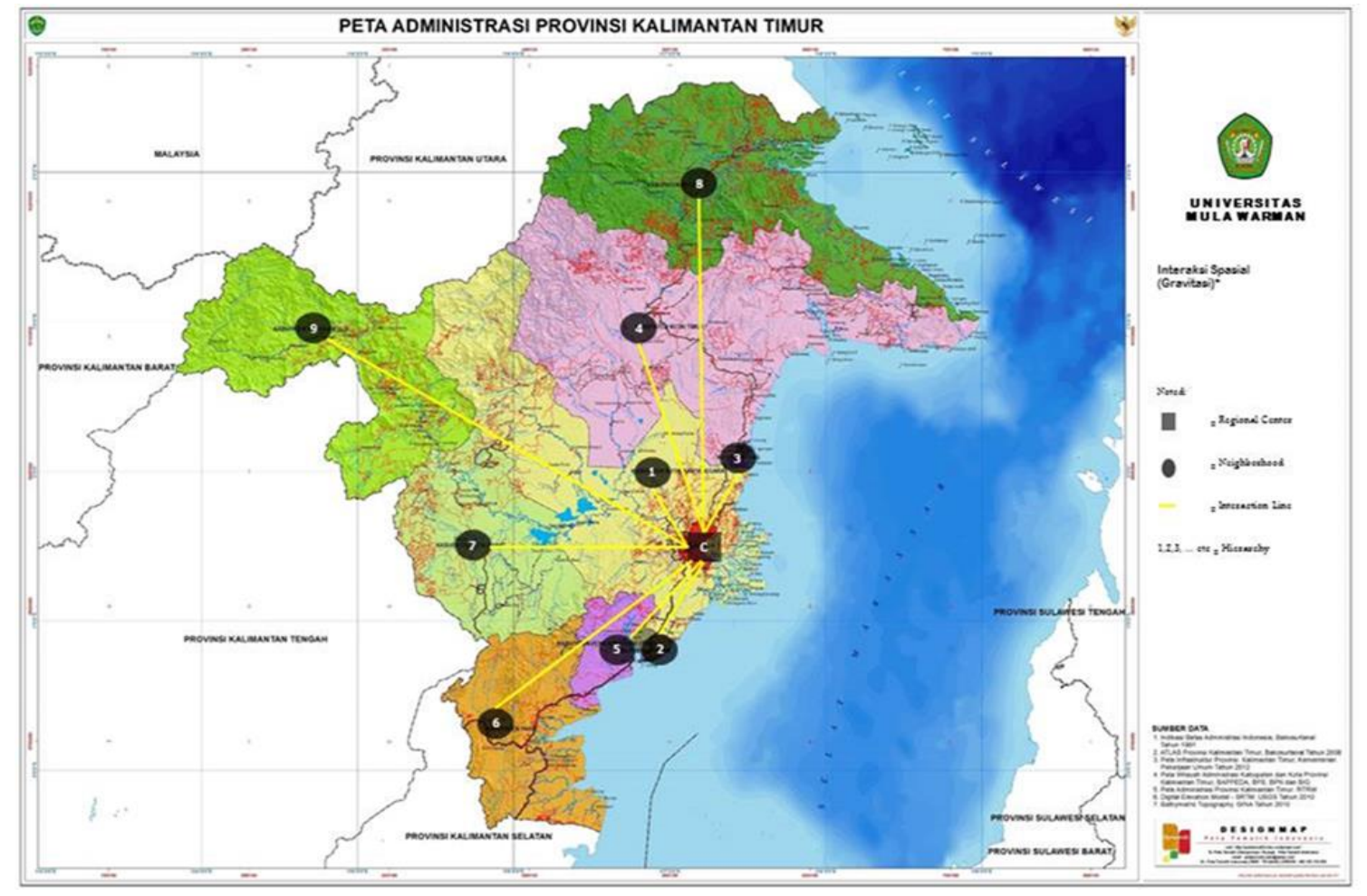

Figure 6. Map of strength of spatial interaction of Samarinda City and region surrounding in East Kalimantan Province Source: Authors calculation

This map also shows that, the geographical location that tends to the north and east has the strength of interaction with the service centers of Samarinda City, namely, Kutai Kartanegara Regency, East Kutai Regency, Bontang City, and Balikpapan City. Meanwhile, the Regency area with a geographical location in the southern part of the Province of East Kalimantan, which has the category of strength of the area of medium interaction, among others, North Penajam Paser and Paser Districts as a link by land and water to neighboring regions (South Kalimantan Province).

Regional Regencies and Cities whose geographical location tends to be located in the northern and eastern parts of East Kalimantan are not recommended to develop new regional service centers, because these areas can still be served and supported by Samarinda City. For some regions located in the west (bordering the provinces of West Kalimantan, Central Kalimantan, and the State of Malaysia) and the north (opposite the North Kalimantan Province) new service centers must be developed, because these regions have weak interaction strengths with the City service centers Samarinda as the capital of East Kalimantan.

Supported by the previous empirical data, which explained that during 2014-2018 the distance that connects the regional center with its surrounding area did not change, so that the impact on the northern region (Berau District) had spatial interaction with the 8 th hierarchy because the distance to the Capital was around $547 \mathrm{Km}$ and the western part of East Kalimantan Province, namely Mahakam Ulu Regency, belongs to the lowest hierarchy (rank 9) with the longest distance $(600 \mathrm{Km})$. On the other hand, the nearest neighboring area, such as Kutai Kartanegara Regency with its administrative center in Tenggaron District, is only around 31 $\mathrm{Km}$ towards Samarinda City. The main component of the connecting distance to the Capital (central region) uses the comparison of the central government between region $\mathrm{A}$ and region $B$.
Demographic composition used as a reference or comparison, is also used in indicators in Gravity Analysis. The main reason for Mahakam Ulu Regency as the outermost and border area, and has the most recent hierarchy is the low population in 5 periods of time, which is on average 25,987 people or contributes $0.76 \%$ to the population in East Kalimantan Province in the aggregate. In contrast, the strongest and most dominant hierarchy is the relationship between Samarinda City and Kutai Kartanegara District which has an average population of 717,693 people (20.95\%) of the total population. The migration of people from both regions, especially at the end of the evening (Saturday and Sunday) has a very significant impact and makes the economy in the growth center (the capital) flowing swiftly, so that the District of Kutai Kartanegara relies heavily on Samarinda City in terms of production, distribution and consumption for goods and services.

It is no less interesting to see the dependence or spatial interaction between the reference area (Samarinda) and Balikpapan City (2nd hierarchy). Equally included as Big Cities on Kalimantan Island and Eastern Indonesia, both have very large population capacities. For Samarinda City, in just 5 years there were 812,473 people or $23.71 \%$ of the population of East Kalimantan who depend their lives on supporting economic sectors, while in Balikpapan City with basic sectors such as: manufacturing industry, goods and retail trade, and finance, and services, information and telecommunications, has an impact on the total population of 615,394 people $(17.96 \%)$ of the total population in East Kalimantan. On the labor side, it is clear that these two strategic areas have a very large share in the heart of the economy of East Kalimantan Province. With the achievement of the Human Development Index (HDI) and population productivity that is fairly evenly compared to other regions, it will have a real impact on the development of economic potential. 
The appeal of the two regions is not only in economic terms. The main supporters in this case are the dependence on the service and tourism sector, as well as the transportation or transportation sector from the capital city (Samarinda) with the city of Balikpapan. Although Samarinda City currently has a major airport, namely Aji Pangeran Tumenggung Pranoto International which is located in the connecting area (Kutai Kartanegara Regency, East Kutai, and Bontang City), but there is still a large enough migration intensity from several surrounding areas coming to using the International Airport in the city of Balikpapan (Sultan Aji Muhammad Sulaiman Sepinggan), this is since the pre-facility facilities at Samarinda's new airport are still incomplete, fares (costs) of flight tickets that are difficult to reach, and so on. Also, dependence on the tourism side causes Samarinda City to Balikpapan City to be quite close, which can be seen from local tourist visits on several beach tourism (Lamaru, and hotels, and sea restaurants) in Balikpapa City, especially on holidays, Saturday and Sunday. Evening.

The movement of people from villages to cities or commonly known as urbanization is one of the factors increasing population density on the island of Java. This is caused by uneven development. Just imagine, almost all the centers of facilities such as education, economy and government are on the island of Java, no wonder that most of the Indonesian population is focused only on the island of Java because for them is a field to improve their lives, even though they know that the population of the island Java is already crowded.

Comparison of development on the island of Java with other islands that are very far away makes the island of Java more densely populated while other islands such as Kalimantan and other large islands are becoming increasingly left behind. Not long ago, we heard that Indonesians who were on the border with Malaysia preferred to become citizens of neighboring countries because the facilities they needed were closer to neighboring countries than in their own country, and this also became an unavoidable population problem caused by uneven development. In various regions in Indonesia.

The effort carried out by the government to smooth the population of Indonesia is through resettlement or what is called transmigration. Some residents from densely populated areas are moved to areas that are still empty or lacking in inhabitants. In the Republic of Indonesia Law No. 3 of 1972, what is meant by transmigration is resettlement of people from one new area and making new settlements, the arrival of transmigration to various regions on the island of Kalimantan, especially the Province of East Kalimantan, has a significant influence in developing regions in occupy and also provide a new field of work.

It can be seen the decline in community self-help presentation compared to funds from central assistance, this is due to problems of the rural economy itself in the village, experiencing a striking change: modernization of agriculture brings higher production, migration to the city results in labor shortages in several places, and turn back resulting in further mechanization. The nature of rural agriculture in the nineties was completely different from the general pattern prevailing in 1970. At that time the rhythm of life and the rhythm of work depended on the monsoon, which determined when people could plant and harvest, but the most striking was the rural urbanization, due to contact with the city becomes stronger then daily life and Repelita III transmigration program becomes a priority in the distribution of population, because the government policy regarding the transmigration program has the expected impact of creating a prosperous and prosperous society. Furthermore, in the framework of implementing more equitable national development throughout the region, efforts will be made to harmonize the growth rates between regions, among others in increasing inter-regional and inter-island transportation, providing assistance and stimulation to increase development of relatively backward regions, and a more even distribution of population through transmigration, where the area of origin was not promising, and towards new areas is very promising for their future.

Humans have many needs that need to be fulfilled. These needs can be in the form of goods and services if the goods are clothing and boards if the services are taxis in the form of ships that bring people to various city centers in East Kalimantan, such as: Samarinda, Balikpapan, and Bontang. Needs arise because of physical or physical demands to be able to live properly as humans. In this case, human needs are diverse and cannot be satisfied because humans have the nature of always feeling inadequate. The more facilities that are owned, the more needs that are felt less fulfilled, then the higher the level of income, the more or more needs. Besides, the natural environment in which humans are located encourages people to act to adapt to their environment so that they inevitably do so.

The linkage between regions to and from the city of Samarinda for the largest travel of goods in the surrounding regencies and cities, this shows that there is interdependence in commodities and economic activities between the regions concerned. This linkage is supported by the availability of physical infrastructure, namely the road network. The linkage between regions to and from the city of Samarinda for the travel of people with other provinces or regions on the island of Borneo, especially East Kalimantan is the largest compared to other regions in Indonesia, especially in cities that have seaports and airports, so that the accessibility between regions is quite high. This shows the dependence in terms of human relations, especially related to work between the two regions is very high. The relationship that occurs that forms the linkage between Samarinda City and other regions is a mutually beneficial relationship.

Many of the previous studies identified the driving forces or determinants of urban growth as mainly physical, socioeconomic, and neighborhood factors. Topography, slope and elevation are the important physical factors of urban growth [51]. The elevated areas were usually developed in the early stage of urban development as they cannot be invaded by floods [52].

\section{CONCLUSIONS}

East Kutai Regency has consistently become a regional interaction which is categorized as fast progressing and growing in East Kalimantan Province. This is due to the achievement of the per capita Gross Regional Domestic Product (GRDP) and East Kutai Regency economic growth indicators above the average reference area, in this connection the level of the Province of East Kalimantan. East Kutai Regency is considered to have regional services within the typology of the East Kalimantan Province. Intra-regionally, there has been a progressive and rapid regional integration for East Kutai Regency. 
Berau Regency has become a regional growth center interaction in East Kalimantan Province. This fact is supported by the economic growth performance with an average rate of $5.18 \%$, compared to the growth rate of East Kalimantan Province which is $1.11 \%$. The existence of a spatial pattern of growth pole development on the coast of East Kalimantan, such as Berau Regency can lead to a unidirectional relationship between the island's coastal region and the inland areas contained therein. Growth pole has been built in the coastal area of Berau Regency, to prevent inequality since the beginning, so that contributions or contributions from the trade, service and tourism sectors have supported and made a big impact on the economy of Berau Regency in these 5 periods.

Regional interaction with Samarinda City (the Provincial Capital) with medium and strong categories occurs in regions whose geographical location tends to be in the eastern and southern parts of East Kalimantan Island. The growth center area of Samarinda City with Kutai Kartanegara Regency is the highest potential attraction (spatial) interaction in East Kalimantan Province. The close distance in connecting the two government centers and with a large population composition, resulted in the most dominant spatial dependence between Samarinda City and Kutai Kartanegara Regency.

As a growth center in East Kalimantan Province, it is still concentrated in the capital, Samarinda City. For economic growth to be more evenly distributed throughout the region, regional and central governments need to work together to make efforts to increase the availability of social, economic facilities with priority in the lowest order regions. Berau Regency and East Kutai Regency can be used as a growth center area to support the 2019-2024 Spatial Planning (RTRW) document for several years later to be recommended as a National Center for Activity (PKN).

The regions that are the back regions (hinterland) of growth centers, need to prioritize economic development by increasing services through the provision and development of facilities and infrastructure. Development of transportation facilities and infrastructure to support the smooth running of economic activities such as road networks and transportation facilities that can foster and enhance interaction or movement of people, goods and services between the growth center and the surrounding area, so that the economic activities of the Regency / City in East Kalimantan Province are not as the center of growth also experiences growth.

Mahakam Ulu Regency as a new area (after the division with West Kutai Regency in 2012) with the weakest value of regional interaction (hierarchy IX) to Samarinda City, it is recommended to develop a new growth center to reduce local disparities that occur. Based on the analysis of spatial interactions using Gravity, a regional regional service center development formulation in East Kalimantan Province was formulated by forming a regional planning scheme into four zones. The western and eastern zones are based on forest land, and the north and south are based on coastal areas. The western development center is centered in Mahakam Ulu Regency with the Capital of Long Bagun (directly adjacent to the State of Malaysia, Central Kalimantan, and West Kalimantan Provinces), then in the southern part bordering South Kalimantan, centered in Paser Regency (Capital of Tanah Grogot). Meanwhile, the development area of the eastern part of East Kalimantan Province is centered in East Kutai Regency (the Capital of Sangata) which connects the main route to North Kalimantan Province and the northern position of Berau Regency with the regional center in Tanjung Redeb plays a major role as a vital link with the area of North Kalimantan Province.

\section{ACKNOWLEDGMENT}

We would thanks to Dean of the Faculty of Economics and Business - Mulawarman University (Prof. Dr. Hj. Syarifah Hudayah, SE, M.Si), Dean of the Faculty of Agriculture Mulawarman University (Dr. Ir. Rusdiansyah, M.Si), Head of Sekolah Tinggi Ilmu Ekonomi Samarinda (Drs. Muhammad Lutfi, ASK, M.T), Anonymous Reviewers, and the Editor in Chief. The author is solely responsible for the content and the views expressed.

\section{REFERENCES}

[1] Taaffe, E.J. (2001). Spatial Interaction. In International Encyclopedia of the Social \& Behavioral Sciences. https://www.sciencedirect.com/topics/computerscience/spatial-interaction.

[2] Tan, R., Zhou, K., He, Q., Xu, H. (2016). Analyzing the effects of spatial interaction among city clusters on urban growth-case of Wuhan. Sustainability, 8(8): 759. https://doi.org/10.3390/su8080759

[3] Reilly, W.J. (1931). The law of retail gravitation. Slippery Rock University, New York.

[4] Wijaya, A., Ilmi, Z., Darma, D.C. (2020). Economic performance: leading sector, economic structure and competitiveness of export commodities. Journal of Business Economics and Environmental Studies, 10(3): 35-42. https://doi.org/10.13106/jbees.2020.vol10.no3.35

[5] Bintarto, R. (1984). Interaksi Desa-Kota dan Permasalahannya. Ghalia Indonesia, Yogyakarta. http://library.um.ac.id/freecontents/index.php/buku/detail/interaksi-desa-kota-danpermasalahannya-r-bintarto-8728.html.

[6] Perroux, F. (1955). Note sur la notion de pole de croissance. Economie Appliquée, 8: 307-320. https://www.researchgate.net/profile/Jandir_Ferrera_de _Lima/publication/228923964_Notes_sur_les_poles_de _croissance_et_les_strategies_territoriales_au_Quebec/l inks/595167eea6fdcc218d24c23e/Notes-sur-les-polesde-croissance-et-les-strategies-territoriales-auQuebec.pdf.

[7] Tarigan, R. (2004). Ekonomi Regional Teori dan Aplikasi. Bumi Aksara, Jakarta. https://books.google.co.id/books/about/Ekonomi_region al.html?id=hb05oLQBneQC.

[8] Giyarsih, S.R. (2012). Koridor antar kota sebagai penentu sinergisme spasial. Tata Loka, 14(2): 90-97. https://doi.org/10.14710/tataloka.14.2.90-97

[9] Giyarsih, S.R. (2014). The role of Yogyakarta and Surakarta cities in the intensity of the regional transformation of two villages located in the YogyakartaSurakarta corridor. Romanian Review of Regional Studies, 10(1): 15-22.

[10] Yunus, H.S. (2008). Dinamika Wilayah Peri Urban, Determinan Masa Depan Kota. Yogyakarta: Pustaka Pelajar. https://www.goodreads.com/book/show/9354737dinamika-wilayah-peri-urban.

[11] Giyarsih, S.R., Fauzi, N. (2016). Factors That affect 
urban sprawl symptoms in sub urban areas of Yogyakarta. Universitas Gadjah Mada, Yogyakarta.

[12] Handayeni, K.D., Ariastita, P.G. (2014). Keberlanjutan transportasi di Kota Surabaya melalui pengembangan TOD (Transit Oriented Development). Tata Loka, 16(2): 108-115. https://doi.org/10.14710/tataloka.16.2.108-115

[13] Sriartha, I.P., Giyarsih, S.R. (2015). The effect of regional development on the sustainability of local irrigation system (A case of subak system in Badung Regency, Bali Province). Forum Geografi, 29(1): 31-40. https://doi.org/10.23917/forgeo.v29i1.789

[14] Talitha, T., Hudalah, D. (2014). Model kerjasama antar daerah dalam perencanaan sistem transportasi wilayah. Tata Loka, 16(4): 194-208. https://doi.org/10.14710/tataloka.16.4.194-208

[15] Basuki, Y., Akbar, R., Pradono, P., Miharja, M. (2013). Komunitas online: Pergeseran terminologi komunitas dari Geddesian menuju era informasi dalam konteks perencanaan transportasi perkotaan. Tata Loka, 15(1): 63-75. https://doi.org/10.14710/tataloka.15.1.63-75

[16] Hamidah, N., Rijanta, R., Setiawan, B., Marfai, M.A. (2014). Kajian transportasi sungai untuk menghidupkan kawasan tepian Sungai Kahayan Kota Palangkaraya. $\begin{array}{lll}\text { Tata } & \text { Loka, } & 16(1) \text { : }\end{array}$ https://doi.org/10.14710/tataloka.16.1.1-17

[17] Kuncoro, M. (2002). Analisis Spasial dan Regional: Studi Aglomerasi \& Kluster Industri Indonesia. UPP AMP YKPN, Yogyakarta. http://opac.lib.ugm.ac.id/index.php?mod=book_detail\& sub=BookDetail\&act=view \&typ=htmlext\&buku_id=60 47\&obyek_id=1.

[18] Mehrtens, J.M., Abdurahman, B. (2007). Regional Marketing: Buku Panduan untuk Menarik Investasi Melalui Aliansi Pembangunan Daerah. Konrad Adenauer Stiftung, Jakarta https://kinandika.wordpress.com/2012/09/16/reviewregional-marketing-buku-panduan-untuk-menarikinvestasi-melalui-aliansi-pembangunan-daerah/.

[19] BPS-Statistics of East Kalimantan Province. (2019). East Kalimantan in Figures 2019. Sekar Mulya, Samarinda. https://kaltim.bps.go.id/publication/2019/08/16/a9deb98 09e0b2606ce96573f/provinsi-kalimantan-timur-dalamangka-2019.html.

[20] Reilly, W.J. (1929). Methods for the Study of Retail Relationships. Studies in Marketing, 4 Bureau of Business Research, The University of Texas, Austin. https://repositories.lib.utexas.edu/handle/2152/60544.

[21] Grime, K. (1976). Book Review: An Introduction to Regional Planning: by JOHN GLASSON. Urban Studies, 13(1): $88-89$. https://doi.org/10.1080/00420987620080151

[22] Kasikoen, K.M. (2011). Keterkaitan Antar Wilayah (Studi Kasus: Kabupaten Cilacap). Jurnal Planesa, 2(2): 146-153.

https://ejurnal.esaunggul.ac.id/index.php/planesa/article/ view/548.

[23] O'Kelly, M.E. (2015). Spatial interaction. International Encyclopedia of the Social \& Behavioral Sciences, 23(2): 152-156. https://doi.org/10.1016/B978-0-08-0970868.72062-9

[24] Douglass, M. (1998). A regional network strategy for reciprocal rural-urban linkages: An agenda for policy research with reference To Indonesia. Third World $\begin{array}{lll}\text { Planning } & \text { Review, } & \text { 20(1): }\end{array}$ https://doi.org/10.3828/twpr.20.1.f2827602h503k5j6

[25] Miro, F. (2005). Perencanaan Transportasi untuk Mahasiswa Perencana dan Praktisi. Erlangga, Padang. http://36.67.167.42:8123/inlislite3/opac/detailopac $? \mathrm{id}=34361$.

[26] Sjafrizal, S. (2012). Ekonomi Wilayah dan Perkotaan. Raja Grafindo Persada, Jakarta. http://www.rajagrafindo.co.id/produk/ekonomiwilayah-perkotaan/.

[27] Gorter, C., Nijkamp, P. (2001). Location Theory. In International Encyclopedia of the Social \& Behavioral Sciences.

https://www.sciencedirect.com/topics/economicseconometrics-and-finance/regional-economics.

[28] Perroux, F. (1988). The pole of development' s new place in a general theory of economic activity. In: Higgins, B., \& Savoie, D (Eds.). Regional Economic Development: Essays in Honour of FrancË ois Perroux, pp. 48-76. Unwin Hyman, Boston. https://doi.org/10.4324/9781315103242-3

[29] Adisasmita, R. (2005). Dasar-dasar Ekonomi Wilayah. Graha Ilmu, Jakarta. Retrieved from http://docplayer.info/52308386-Dasar-dasar-ekonomiwilayah.html.

[30] Romer, P.M. (1990). Endogenous technological change. Journal of Political Economy, 98(5): 71-102. https://doi.org/10.3386/w3210

[31] Grossman, G.M., Helpman, E. (1991). Quality ladders in the theory of growth. The Review of Economic Studies, 58(1): 43-61. https://doi.org/10.2307/2298044

[32] Barnard, J.R., Macmillan, J.A., Maki, W.R. (1969). Evaluation models for regional development planning. Papers of the Regional Science Association, 23: 117-138. https://doi.org/10.1007/BF01941878

[33] Sala-i-Martin, X. (2006). The world distribution of income: Falling poverty and... convergence, period. The Quarterly Journal of Economics, 121(2): 351-397.

[34] Richardson, H.W. (1978). The state of regional economics: A survey article. International Regional Science $\quad$ Review, 3(1): 1-48. https://doi.org/10.1177/016001767800300101

[35] Mindlin, Y.B., Stolyarov, N.S., Novikova, N.V., Smolentsev, V.M., Tikhomirov, E.A. (2018). Evaluation of competitive advantages of regional economic clusters. Espacios, 39(31): 1-14.

[36] BPS-Statistics of Indonesia. (2009). Perbandingan Perubahan Klasifikasi Produk Domestik Bruto (PDB) menurut Lapangan Usaha Tahun Dasar 2000 dan 2010. Klasifikasi Baku Lapangan Usaha Indonesia (KLBI). Cetakan III. BPS-Statistics, Jakarta. https://www.bps.go.id/subject/52/produk-domestikregional-bruto--lapangan-usaha-.html.

[37] Todaro, M.P., Smith, S.C. (2011). Economic Development (11 th ed.). Pearson Education Limited, Harlow.

[38] Tarigan, R. (2007). Perencanaan Pembangunan Wilayah. Edisi Revisi. Bumi Aksara, Jakarta. http://library.um.ac.id/freecontents/index.php/buku/detail/perencanaanpembangunan-wilayah-robinson-tarigan-40555.html.

[39] Darma, D.C. (2019). Determinants of the gross regional domestic product of east Kalimantan province: Macroeconomic variable review. Review of Integrative Business and Economics Research, 9(1): 232-241. 
[40] Arikunto, S. (2000). Metode Penelitian Kualitatif. Bumi Aksara, Jakarta. https://id.scribd.com/doc/100741355/DownloadMetode-Penelitian-Karya-Suharsimi-Arikunto.

[41] Arku, G. (2006). The housing and economic development debate revisited: economic significance of housing in developing countries. Journal of Housing and the Built Environment, 21, 377-395. https://doi.org/10.1007/s10901-006-9056-3

[42] Jacob, J., Hasan, N. (2016). Determining the centers of economic growth and regional development using scalogram analysis (An empirical study in west Halmahera regency, Indonesia). IOSR Journal of Economics and Finance, 7(4): 31-36. https://doi.org/10.9790/5933-704033136

[43] Sugiyono, S. (2009). Metode Penelitian Kuantitatif, Kualitatif dan R\&D, Cetakan 8. Alfabeta, Bandung. http://cvalfabeta.com/product/metode-penelitiankuantitatif-kualitatif-dan-rd-mpkk/.

[44] Ermawati, E. (2010). Analisis Pusat Pertumbuhan Ekonomi Pada Tingkat Kecamatan Di Kabupaten Karanganyar Provinsi Jawa Tengah. Thesis. Fakultas Ekonomi, Universitas Sebelas Maret, Surakarta. https://digilib.uns.ac.id/dokumen/detail/12513/Analisispusat-pertumbuhan-ekonomi-pada-tingkat-kecamatandi-Kabupaten-Karanganyar-Provinsi-Jawa-Tengah.

[45] Aswandi, H., Kuncoro, M. (2002). Evaluasi Penetapan Kawasan Andalan: Studi Empiris di Kalimantan Selatan 1993-1999. Journal of Indonesian Economy and Business, 17(1): 27-45 https://doi.org/10.22146/jieb.6703

[46] Klassen, L.H. (1987). Economic Impact and Implications of Shelter Investment. In Shelter, Settlement and Development. Edited by Rodwin, L., pp 35-59. Allen Unwin,

Boston. https://digitalcommons.calpoly.edu/cgi/viewcontent.cgi ?article $=1035 \&$ context $=$ crp_fac

[47] Daldjoeni, N. (2014). Geografi Kota dan Desa. Ombak, Yogyakarta. http://penerbitombak.com/product/geografi-kota-dandesa/.

[48] Rogerson, C.M. (1975). Industrial Movement In An Industrializing Economy. Journal South African Geographical Journal, 57(2), 88-103. https://doi.org/10.1080/03736245.1974.10559552

[49] Enrique, G., Joaquim, M., William, T. (2015). The modern regional policy paradigm: Rationale and evidence from OECD countries. GOT - Geography and Spatial Planning Journal, 7: 9-44. https://doi.org/10.17127/got/2015.7.001

[50] Emalia, Z., Farida, I. (2018). Identifikasi Pusat Pertumbuhan dan Interaksi Spasial di Provinsi Lampung. Jurnal Ekonomi \& Studi Pembangunan, 19(1): 61-74. https://doi.org/10.18196/jesp.19.1.4100

[51] Ma, Y., Xu, R. (2010). Remote sensing monitoring and driving force analysis of urban expansion in Guangzhou City, China. Habitat International, 34(2): 228-235. https://doi.org/10.1016/j.habitatint.2009.09.007

[52] Dewan, A.M., Yamaguchi, Y. (2009). Land use and land cover change in Greater Dhaka, Bangladesh: Using remote sensing to promote sustainable urbanization. Applied Geography, 29(3): 390-401. https://doi.org/10.1016/j.apgeog.2008.12.005 